\title{
Incidence of protein deficiency in relation to different diets in India
}

\author{
By P. V. SUKHATME \\ Food and Agriculture Organization, Rome \\ (Received I2 August 1969-Accepted I I December 1969)
}

\begin{abstract}
I. A method is presented for estimating the incidence of protein deficiency which takes due note of the association of protein deficiency with inadequate calorie intake and is applied to the data from dietary surveys in India. It is concluded that in only about one out of ten cases does protein deficiency occur as a direct result of inadequate protein intake. In the vast majority of cases protein deficiency is the result of inadequate intake of total energy. Protein which does not bring calories with it is therefore unlikely to make any significant contribution to the solution of the protein problem in India.

2. It is shown that diets based on cereals and pulses normally consumed by the people can meet man's needs for protein at all ages provided enough food is taken to satisfy his energy needs. It is, however, important to ensure for infants a smooth transition from breast milk to solid diets. Special care is also necessary in the case of pregnant and lactating women.

3. The nature of protein deficiency is discussed in relation to different dietary patterns. The continuity implied in the bivariate distributions of calorie and protein intake is seen to provide a possible explanation of the experimental results on the development of kwashiorkor observed in animals on a diet short of both calories and protein and on diets predominantly short of protein.
\end{abstract}

Previous estimates of the incidence of protein deficiency are based on the simple criterion of whether the diet fulfils an accepted requirement for protein, regardless of the energy content (Sukhatme, 1963, 1965, 1966). However, even when the diet provides an adequate intake of protein, the symptoms of deficiency may still arise if it does not also provide adequate calories, since under these circumstances protein is utilized at reduced efficiency. If it can be shown that a large proportion of the incidence of protein deficiency is an indirect result of low energy intake, current policy measures to close the protein gap by laying great emphasis on the production and use of edible protein regardless of the energy content will need to be critically reviewed. It is the object of this paper to assess the relative contributions to the incidence of protein deficiency resulting from different patterns of diet and to set out briefly the implications of this assessment.

\section{METHODS AND FINDINGS}

\section{Material}

The information used for this paper comes from dietary surveys conducted in the rural areas of Madras and Bihar, India. The surveys were carried out by the State Nutrition Units under the guidance of the Indian Council of Medical Research and covered 1022 households in thirty-eight villages of nine districts in Madras and 2474 households in I I 0 villages of twelve districts in Bihar. The surveys covered the period $1955^{-63}$ for Madras and $195^{2-60}$ for Bihar. The method of collecting information was by interview, together with the weights of food consumed by the 
households for each meal, morning and evening. The consumption was recorded daily for 7 consecutive days in Madras and for Io consecutive days in Bihar. The income of the households selected was recorded for Madras but not for Bihar.

The selection of villages and households within villages was evidently not at random. The choice of villages was to some extent arbitrary and the selection of households appears to have been made with a view to getting co-operation. Considering, however, that the surveys were spread over several years and different seasons of each year and over several districts of the States, the results are believed to provide a reasonably reliable picture of the consumption pattern of households in the low-income groups of the rural areas.

To prepare the results for this study the recorded values for consumption of each foodstuff were converted into calories and protein using the nutritive values of Indian foodstuffs tabulated by Aykroyd, Gopalan \& Balsubramanian (I966). The numbers of nutrition units for calories and protein were separately calculated for each household on the basis of the age and sex of the members of the family and using the latest calorie and protein requirement scale (Indian Council of Medical Research, 1968). The results were tabulated in the form of bivariate distributions of calorie and protein intake in households expressed on a nutrition unit basis. The households were regarded as consisting of an equivalent number of nutrition units, each of which has the requirements of the 'reference' man, namely $2800 \mathrm{kcal}(\mathrm{II} \cdot 7 \mathrm{MJ})$ and $30 \mathrm{~g}$ of reference protein per $d$. In these two areas, the average household consists of four nutrition units. The values of protein tabulated were those of 'reference' protein, i.e. protein having a net utilization (NPU) of $100 \%$. In converting the dietary protein intake of each household into 'reference' protein, animal protein in the diet was assumed to have a NPU of 80 and vegetable protein to have a NPU of 50 . The former is approximately the value of NPU determined for milk, which accounts for the major part of animal protein in the country. The latter is a little lower than NPU calculated for vegetable protein in the average diet. If anything, these assumptions put estimates of the protein intake in households slightly on the conservative side since no account is taken of any possible amino acid supplementation. The bivariate distribution for Madras is shown as an example in Table $\mathbf{I}$.

\section{Protein and calorie requirements}

The requirement levels used in this paper are reproduced in Table 2. They are taken from the latest recommendations on the subject by the Nutrition Advisory Committee of India (Indian Council of Medical Research, 1968). The recommendations for protein are based on the factorial approach developed by the FAO/WHO Committee on Protein Requirements (FAO, 1965) and represent the sum of the estimated needs for maintenance and growth based on the experimental evidence available in India. For age groups for which experimental evidence available in the country was inadequate, the Nutrition Advisory Committee drew upon the recommendations made by the FAO/WHO Committee.

Table 2 shows the recommended protein requirements at two levels, one representing the mean and the other the mean $+20 \%$. The former is called requirement 
Vol. 24

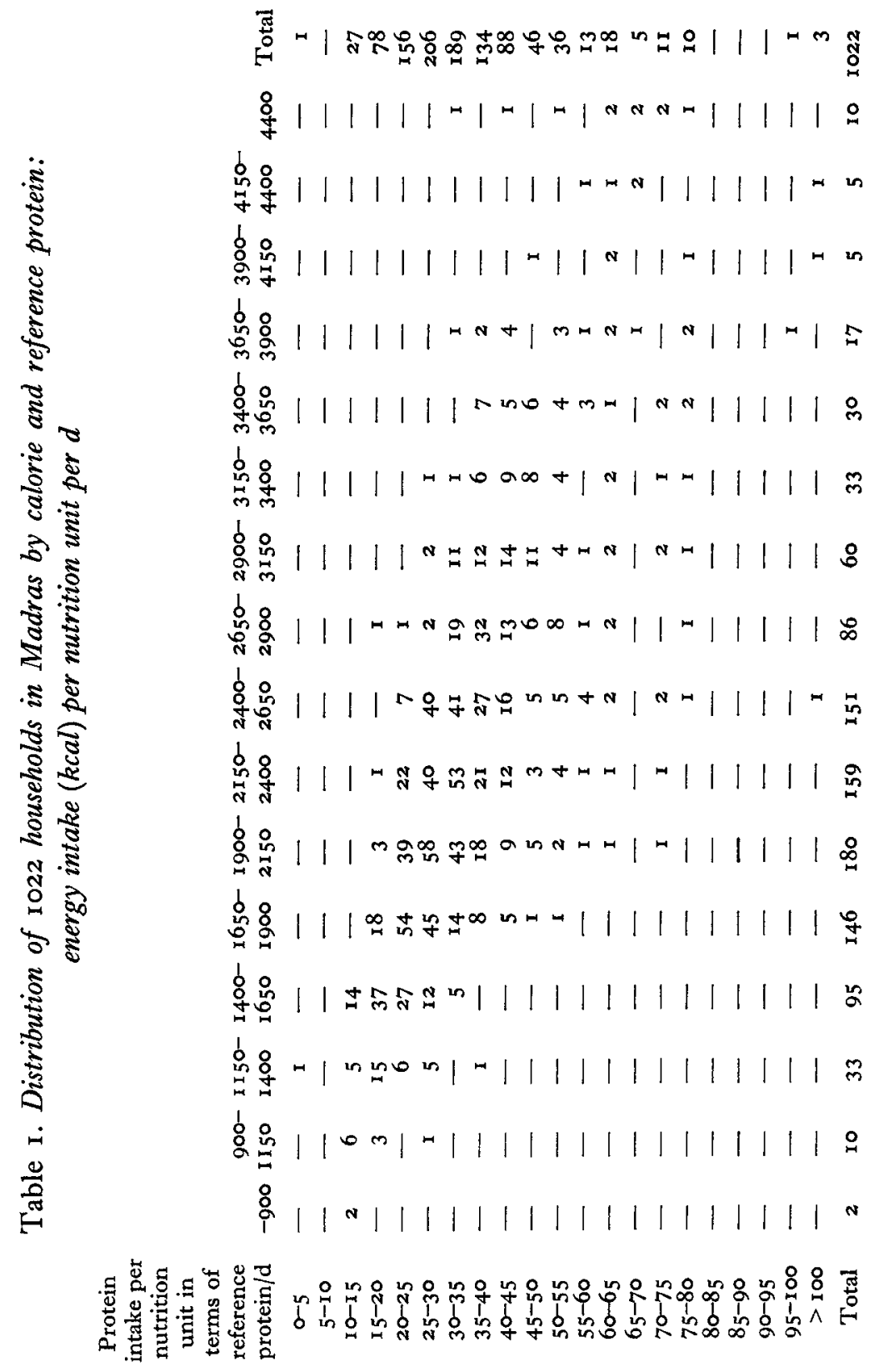


in the table; the latter is called allowance. The margin of $20 \%$ represents the allowance to cover individual variation. The values are also given in terms of calories derived from 'reference' protein expressed as a percentage of the calorie needs (NDpCal \%). This latter form is particularly suitable for expressing protein requirements needed for this study because, if a diet has a value equal to or greater than the $\mathrm{NDpCal} \%$ corresponding to the allowance set out in the table, it implies that protein requirements of most individuals will be met whenever the diet is adequate in energy.

Table 2. Recommended daily protein requirements and allowances given as reference protein and as $\mathrm{NDPCal} \%$

\begin{tabular}{|c|c|c|c|c|c|}
\hline \multirow[b]{2}{*}{$\begin{array}{c}\text { Age } \\
\text { (years) }\end{array}$} & \multirow{2}{*}{$\begin{array}{c}\text { Protein } \\
\text { allowance } \\
\text { (g) }\end{array}$} & \multirow{2}{*}{$\begin{array}{l}\text { Mean } \\
\text { protein } \\
\text { requirement } \\
(\mathrm{g})\end{array}$} & \multirow{2}{*}{$\begin{array}{l}\text { Calorie } \\
\text { requirement } \\
\text { (kcal) }\end{array}$} & \multicolumn{2}{|c|}{ NDpCal \% } \\
\hline & & & & $\begin{array}{l}\text { Mean } \\
\text { requirement }\end{array}$ & Allowance \\
\hline $0-0.5$ & $2 \cdot I^{*} / \mathrm{kg}$ & 一 & $120 / \mathrm{kg}$ & - & $5 * 7$ \\
\hline $0.5-1$ & $\mathrm{I} \cdot 7^{*} / \mathrm{kg}$ & 一 & $110 / \mathrm{kg}$ & - & $5 \cdot 1$ \\
\hline$I-3$ & 9 & $7 \cdot 5$ & 1200 & $2 \cdot 5$ & $3 \cdot 0$ \\
\hline $4-6$ & I I & $9 \cdot 5$ & 1500 & $2 \cdot 5$ & 3.0 \\
\hline $7-9$ & 17 & 13.5 & 1800 & $3 \cdot 1$ & $3 \cdot 7$ \\
\hline $10-12$ & $2 I$ & 17 & 2100 & $3 \cdot 2$ & $3 \cdot 9$ \\
\hline 13-I 5 : boys & 28 & 23 & 2500 & 3.7 & $4 \cdot 4$ \\
\hline girls & 25 & 21 & 2200 & $3 \cdot 7$ & $4 \cdot 5$ \\
\hline 16-19: boys & 30 & 25 & 3000 & $3 \cdot 3$ & 4.0 \\
\hline girls & 25 & 21 & 2200 & 3.7 & $4 \cdot 5$ \\
\hline Adult male & 36 & 30 & 2800 & $4 \cdot 2$ & $5 \cdot I$ \\
\hline Adult female & 29 & 24 & 2200 & 4.4 & $5 \cdot 3$ \\
\hline Pregnant female & 36 & 30 & $2200 t$ & $5 \cdot 4$ & $6 \cdot 5$ \\
\hline Lactating female & 42 & 35 & 2900 & 4.9 & $5 \cdot 8$ \\
\hline
\end{tabular}

It will be seen that both protein and calorie requirements increase with age but the rate of increase with age in protein needs is larger than the rate of increase in calorie needs. This is reflected in the values of $\mathrm{NDpCal} \%$. As will be seen, $\mathrm{NDpCal} \%$ is larger for adults than for children, except for infants under I year for whom the NDpCal \% has the same value as for adults. This is of considerable importance because it shows that the belief that children need protein foods which are much more concentrated in protein than those normally eaten by adults is not well founded. There is also another implication for policy measures. As will be shown later, the NDpCal \% needed by a normal person taking his exact requirements of calories and protein is well covered by a diet based on cereals and pulses for all age groups, including infants, although the latter will need separate consideration owing to the difficulty of giving solid diet.

\section{Incidence of calorie deficiency}

In a well-fed population where no one is calorie-deficient most households would be expected to have their calorie intake per nutrition unit higher than the critical limit given by the average requirement of the 'reference' man $(2800 \mathrm{kcal})$ minus three times the related standard deviation (Sukhatme, 196r). The standard deviation 
of energy expenditure of healthy active adults of the 'reference' type is around $400 \mathrm{kcal}$, and the households on average have four nutrition units for calories. It follows that the critical limit for evaluating the incidence of undernutrition can be placed at approximately $2800-3 \times(400 / \sqrt{4})$, or $2200 \mathrm{kcal}$ assuming negligible wastage of food. From Table $\mathrm{I}$ we see that the proportion of households with an intake less than $2200 \mathrm{kcal}(9.2 \mathrm{MJ})$ per nutrition unit is about one-half. In other words, onehalf of the households surveyed in Madras can be considered to be calorie-deficient or undernourished. When the values are not tabulated in the form of distributions one can approximate to the proportion of calorie-deficient by assuming that the observed distribution has a normal form with mean value of calorie intake and standard deviation equal to those observed and referring to the table of normal deviates to calculate the proportion. Such a calculation gives a value of 0.56 for the proportion of calorie-deficient in Madras and 0.22 for Bihar. The smaller the proportion the larger is likely to be the deviation of the computed value from the observed proportion owing to the departure from the assumption of normality. For Bihar, the observed distribution gives the proportion of one-sixth for the calorie-deficient households.

The incidence of undernutrition in the household does not mean that every member of the household is undernourished. Food is not distributed in proportion to needs, especially in poor households. The same also hold, though to a smaller extent, in households with a calorie intake above the critical limit. For lack of information on individual intake it has been assumed that the two groups broadly counterbalance each other and that, in consequence, the proportion of calorie-deficient households may be equated to the incidence of calorie deficiency in the population.

\section{Incidence of protein deficiency}

Following the same approach as described above, we can estimate the proportion of people with inadequate intake of protein. As Table 2 shows, the average requirement of the 'reference' man weighing $55 \mathrm{~kg}$ is $30 \mathrm{~g} / \mathrm{d}$ of 'reference' protein while the standard deviation of households per nutrition unit of protein is known to be of the order of $I_{5} \mathrm{~g}$ (FAO, 1965$)$. It follows that the critical limit for assessing the proportion of households with inadequate protein intake could be placed at a little over $25 \mathrm{~g}$. In fact, proteins are distributed more unevenly among and within households than calories. It would therefore seem more reasonable to set a cut-off point for the protein distribution at twice the value of the standard error rather than three times the value. Accordingly, the critical limit for evaluating the incidence of protein deficiency in the population can be placed at $30-2 \times 1 \cdot 5$, or $27 \mathrm{~g}$ of 'reference' protein. The observed distribution for Madras given in Table I shows that about one-third of the households have a protein intake of less than $27 \mathrm{~g}$ per nutrition unit. In other words, we conclude that the incidence of protein deficiency in the surveyed population in Madras is about one-third. For Bihar this proportion is found to be very small, being $0 \cdot 05$.

We note that the incidence of protein deficiency is considerably smaller than the incidence of calorie deficiency in the population. It needs to be stressed, however, 
that the incidence of protein deficiency as estimated above represents the proportion of persons with diets inadequate in protein but excludes people who, although having adequate protein in the diet, are not able to utilize it for lack of calories. In other words, the incidence of protein deficiency as estimated above does not represent the total incidence of protein deficiency in the population.

Table 3. A $2 \times 2$ table showing percentage classification of households in rural areas of Madras and Bihar according to whether they are deficient or not in calories and proteins

\begin{tabular}{|c|c|c|c|c|c|c|c|c|c|c|c|c|c|c|c|}
\hline \multirow{3}{*}{$\begin{array}{l}\text { Income } \\
\text { (Rs/month) }\end{array}$} & \multicolumn{12}{|c|}{ Madras } & \multirow{2}{*}{\multicolumn{3}{|c|}{ Bihar }} \\
\hline & \multirow{2}{*}{ 1) } & \multicolumn{2}{|l|}{$0-50$} & \multicolumn{3}{|c|}{$50-100$} & \multicolumn{3}{|c|}{ roo and above } & \multicolumn{3}{|c|}{ All households } & & & \\
\hline & & NPD & Total & $1 \mathrm{PD}$ & NPD & Total & PD & NPD & Total & PD & NPD & Total & I PD & NPD & Total \\
\hline CD & $\begin{array}{c}37 \\
(4 \cdot 8)\end{array}$ & $\begin{array}{c}22 \\
(6 \cdot 8)\end{array}$ & 59 & $\begin{array}{c}30 \\
(4 \cdot 8)\end{array}$ & $\begin{array}{c}24 \\
(6.8)\end{array}$ & 54 & $\begin{array}{c}16 \\
(5 \cdot 2)\end{array}$ & $\begin{array}{c}17 \\
(6 \cdot 4)\end{array}$ & 33 & $\begin{array}{r}28 \\
(4 \cdot 8)\end{array}$ & $\begin{array}{r}2 I \\
(6 \cdot 8)\end{array}$ & 49 & $\left(\begin{array}{r}5 \\
(6 \cdot 0)\end{array}\right.$ & $\begin{array}{c}12 \\
(7 \cdot 6)\end{array}$ & I7 \\
\hline NCD & $\begin{array}{c}9 \\
(4 \cdot 0)\end{array}$ & $\begin{array}{c}32 \\
(6 \cdot 0)\end{array}$ & 4I & $\begin{array}{c}6 \\
(4 \cdot 0)\end{array}$ & $\begin{array}{c}40 \\
(5 \cdot 6)\end{array}$ & $4^{6}$ & $\begin{array}{c}I \\
(4 \cdot 0)\end{array}$ & $\begin{array}{r}66 \\
(6 \cdot 0)\end{array}$ & 67 & $\begin{array}{r}6 \\
\left(4^{\circ} 0\right)\end{array}$ & $\begin{array}{r}45 \\
(5 \cdot 6)\end{array}$ & $5 \mathrm{I}$ & $\overline{(4 \cdot 4)}$ & $\begin{array}{c}83 \\
(6 \cdot 8)\end{array}$ & 83 \\
\hline Total & 46 & 54 & 100 & 36 & 64 & 100 & I7 & 83 & 100 & 34 & 66 & 100 & 5 & 95 & 100 \\
\hline
\end{tabular}

CD (calorie-deficient) and NCD (not calorie deficient), \% households with daily calorie intake per nutrition unit below and above 2200 kcal respectively.

PD (protein-deficient) and NPD (not protein-deficient), \% households with daily protein intake per nutrition unit below and above $27 \mathrm{~g}$ respectively.

Figures in parentheses are mean NDpCal \% of the household diets.

\section{Incidence of calorie and protein deficiency}

We can further extend the above analysis to estimate the proportion of people whose diets are deficient in both calories and proteins. This is done by calculating the proportion of households with both calorie and protein intakes below the respective critical limits. This proportion is about one-quarter for Madras, and for Bihar 0.05.

We can summarize results of the analysis presented in the last three sections in the form of a $2 \times 2$ table, as in Table 3 . It will be seen that the vast majority of the proteindeficient households are also calorie-deficient. This is even truer of Bihar where, in fact, all the protein-deficient households are calorie-deficient.

\section{Protein deficiency associated with inadequate calorie intake}

In the analysis presented above it has been assumed that the utilization of protein in the diet is independent of the calorie intake. This assumption is not valid since, when the diet is inadequate in calories, protein is diverted from its primary function to the provision of energy. Thus Calloway \& Spector (1954) as a result of their observations on nitrogen balance and calorie intakes in young men stated 'To the general principle that on a fixed adequate protein intake, energy level is the deciding factor on nitrogen balance, and that with a fixed adequate caloric intake, protein level is the determinant - may be added a corollary. That is that at each fixed inadequate protein intake there is an individual limiting energy level beyond which increasing calories without protein or protein without calories is without benefit.'

These considerations suggest that in any assessment of the incidence of protein deficiency in the population we cannot be guided by the inadequacy of the protein 
intake alone but must also take into account adequacy of calories. People who take adequate or more than adequate protein but who are not able to utilize it for lack of adequate calories in the diet must obviously be included among those whose diet leads to protein deficiency in the population.

Miller \& Payne (196I) have shown that on average a little over $6 \mathrm{cal}$ are needed for the synthesis of $\mathrm{I} g$ of protein. Since a 'reference' man (FAO, I957) on average needs I $400 \mathrm{kcal} / \mathrm{d}$ for basal metabolism under Indian conditions, it follows that the additional energy for anabolysing protein needed by a 'reference' man will be $120 \times 6 \cdot 2$, or $750 \mathrm{kcal} / \mathrm{d}$. In other words, a 'reference' man will need to have a minimum of $2150 \mathrm{kcal}$ at the physiological level, or about $2200 \mathrm{kcal}(9 \cdot 2 \mathrm{MJ})$ allowing for a small amount of waste, in order that he may achieve a protein balance. This value of 2200 , as we saw already, is approximately the value of the critical limit for calories below which a man can be said to be calorie-deficient.

Given then a fourfold classification for calorie and protein intake in households on a nutrition unit basis, and using $\mathrm{A}, \mathrm{B}, \mathrm{E}$ and $\mathrm{F}$ to denote the porportions of households in the four cells of the $2 \times 2$ table, as shown below, where the dividing

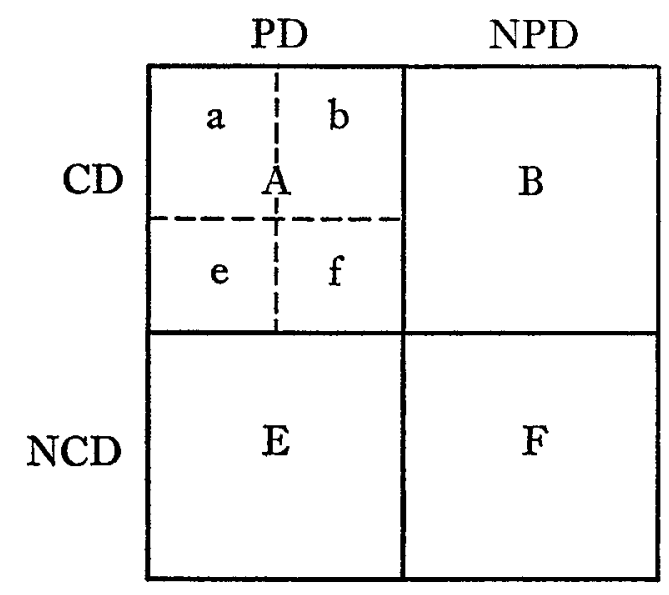

lines are placed at the critical limit for calories and protein, we can express the incidence of protein malnutrition (I) formally thus

$$
\mathrm{I}=\overline{\mathrm{A}+\mathrm{E}}+\mathrm{B} \text {, }
$$

where $\overline{\mathrm{A}+\mathrm{E}}$ represents the incidence of protein deficiency in the population occurring as a result of inadequate protein intake and $B$ represents the incidence of protein deficiency occurring as a result of inadequate total calories in the diet. Substituting in the equation we get

$$
\begin{aligned}
& I \text { (Madras) }=(\overline{28+6}+2 \mathrm{I})=55, \\
& I(\text { Bihar })=(\overline{5+0}+12)=I 7 .
\end{aligned}
$$

It will be seen that the contribution to the total incidence of protein deficiency arising from inadequate calorie intake amounts to $40 \%$ in Madras and is as high as $70 \%$ in Bihar. Clearly, to leave out this contribution in assessing the total incidence of 
protein deficiency in the population would be seriously to underestimate the size of the protein problem in the country. Thus, whereas the incidence of protein deficiency when judged upon protein intake alone is $34 \%$, it becomes $55 \%$ when the interrelationship between proteins and calories is taken into consideration. The respective values for Bihar are 5 and $17 \%$.

The above estimates of the incidence of protein deficiency are not to be taken as indicative of the general dimensions of the problem since they are based on households mainly coming from poor income strata of the population. Nevertheless, the values do serve the purpose of bringing out the relative importance of low protein intake and low calorie intake in causing protein deficiency.

\section{DISCUSSION}

The incidence I of protein deficiency can be expressed as the sum of three separate terms

$$
\mathrm{I}=\mathrm{A}+\mathrm{B}+\mathrm{E},
$$

corresponding to the contents of three cells of the $2 \times 2$ diagram with dietary patterns of households which are distinctly different both from one another and from that of cell $\mathrm{F}$, which has adequate or more than adequate calories and protein.

Term A comprises households whose diet is deficient in both calories and protein but, as Table 3 shows, has NDpCal \% exceeding the mean value of 4.2 needed by the 'reference' man taking his exact requirements of protein and calories and also exceeds the value of 4.7 needed to cover variation among households. (The allowance for individual variation of protein requirements is $20 \%$, so that the allowance for a household of 4 nutrition units would be $+20 / \sqrt{4}=+10 \%$.) It will be seen that $\mathrm{A}$ accounts for $50 \%$ of the protein-deficient households in Madras and $30 \%$ in Bihar. Clearly, the primary need of the households of this cell is to have an adequate quantity of food. To give more protein to households of this cell without ensuring that this protein brings calories with it can hardly serve any purpose.

A bivariate distribution implies a continuous gradation in the diet and in the calorie and protein intake derived therefrom. It is consequently difficult to expect marked clinical signs differentiating individuals of cell $\mathrm{A}$ from those of other cells. One would expect that as a diet decreases in calories and along with it in protein and other associated vitamins and minerals there would be a continuous change from health to disease amongst those receiving it, first marked by subclinical signs associated with poor health and later clinical signs which would distinguish individuals in cell A from those in cell F. A child brought up on an inadequate diet suffers from retardation of body growth to start with. Retardation of growth in this sense represents an attempt on the part of the child to adjust himself to the availability of diet, eventually leading to some sort of equilibrium between body-weight, development and physical activity on the one hand and intake of food on the other. As a group, individuals in cell A can be described as having adapted themselves to this state of equilibrium, aptly described as a condition of 'nutritional dwarfism'. Within the general framework of this adaptation, however, there will be variation from individual to individual depending 
upon their precise position in cell A with some individuals showing more retardation of body growth, a greater degree of emaciation and lower body-weight than others. For example, if one were to imagine that cell $A$ is subdivided into four subcells $a, b$, e and $f$, as shown on p. 483, then children in subcell e of cell $\mathrm{A}$ at the extreme limits of the lower end of protein intake and the higher end of calorie intake, while belonging to the class of 'nutritional dwarfs' would have for their dietary pattern a low value for NDpCal \% similar to that for cell $\mathrm{E}$ and would therefore be susceptible to kwashiorkor in much the same way as would be the children of cell $\mathrm{E}$. With a prolonged period of predominantly protein-deficient diet therefore, one might well expect children of subcell e of cell A, provided they survived, to eventually develop clinical signs of kwashiorkor. This could provide a possible explanation of the experimental results on the development of kwashiorkor reported by Srikantia \& Gopalan (1959) among animals subsisting on a diet short of both calories and protein. For it appears reasonable to expect that if the hypothesis of adaptation is valid then variation in diet resulting in marked deficiency in protein relative to calorie intake within the dietary pattern characteristic of 'nutritional dwarfism' would produce a dietary pattern in subcell e of cell A similar to the dietary pattern of cell $\mathrm{E}$, which is known to lead to kwashiorkor (Ramalingaswami, Deo \& Sood, 196I). On the other hand, if the diet given to experimental animals had a pattern more characteristic of cells a or $\mathrm{b}$, than e of cell $\mathrm{A}$, then the current hypothesis of predominant protein deficiency is evidently inadequate in explaining the development of kwashiorkor as concluded by Gopalan (1968).

We shall next take up term $B$ of the expression for $I$. Households belonging to this cell have adequate or more than adequate protein but are short of calories. We see from Table 3 that this cell has the highest value for NDpCal\% among all the cells, much higher than the mean value of $4 \cdot 2$ needed by the 'reference' man taking his exact requirements of protein and calories and also higher than 4.7 needed to cover variation among households. Clearly, people belonging to this cell do not suffer from shortage of protein as such in their diet but they are not able to utilize the protein fully for lack of energy. As we saw, households must have on average an amount of $2200 \mathrm{kcal}$ at the physiological level per nutrition unit in order to be able to use the protein in their diet to meet their body needs. Cell $\mathrm{B}$, like cell A, therefore presents the problem of ensuring adequate supplies of food of the type normally consumed by the people. As we have seen, some $40 \%$ of the total number of protein-deficient households in Madras and $70 \%$ in Bihar belong to this cell. Most of these belong to the poor-income class and eat a diet providing a high proportion of pulses. Diets represented by this cell, like those of cell $\mathrm{A}$, lead to marasmus. Children brought up on this diet, like those in cell $\mathrm{A}$, show a marked retardation of body growth to start with and eventually adapt themselves to low body-weight and a low degree of physical activity consistent with their intake of energy and other nutrients. However, it appears unlikely that in view of the high value for NDPCal\% of their diet they will develop clinical signs characteristic of kwashiorkor, such as might be observed in children belonging to cell $\mathrm{F}$.

Turning to cell E, we see that it comprises households with adequate or more than adequate calories but receiving inadequate supplies of protein. Their dietary 
pattern has a low value for $\mathrm{NDpCal} \%$, significantly lower than the allowance of 4.7 needed by households on the nutrition unit basis. However, this cell is seen to account for only a small proportion of the total number of protein-deficient households, contributing only about one-tenth of the total number in Madras and none in Bihar. The pressing need of this group is clearly to have more protein irrespective of whether such protein brings calories with it or not.

The dietary pattern represented by this cell is known to lead to subclinical and clinical signs of kwashiorkor. The condition occurs during infancy soon after weaning. As long as an infant is at the breast and during the first 6 months or so of its life it usually receives adequate calories and protein from its mother's milk. But after about 6 months, breast milk no longer provides the needed amounts of calories and protein for satisfactory bodily growth. It is at this stage that a child receives supplements of solid foods. If these are starchy foods which provide additional calories but not protein, then the NDpCal\% of the mixed diet may fall below the value needed to ensure satisfactory growth. Protein deficency will then develop gradually, leading to the clinical signs of kwashiorkor.

$\begin{array}{lccc}\text { Table 4. }{ }^{2 D p C a l} \% \text { in different food mixtures } & \text { providing } 2200 \text { kcal daily } \\ \text { Food mixture } & \text { Rice } & \text { Wheat } & \text { Maize } \\ \text { Staple alone } & 4 \cdot 9 & 5 \cdot 7 & 4 \cdot 8 \\ \text { Staple+30 g legumes } & 6 \cdot 2 & 7 \cdot 0 & 6 \cdot 3 \\ \text { Staple+60 g legumes } & 6 \cdot 7 & 8 \cdot 3 & 6 \cdot 5 \\ \text { Staple+30 g of skim-milk powder } & 7 \cdot 1 & 8 \cdot 0 & 7 \cdot 0 \\ \text { Staple+45 g legumes + } 5 \text { g skim-milk powder } & 6 \cdot 8 & 8 \cdot 8 & 6 \cdot 9\end{array}$

Widespread incidence of protein deficiency associated with the pattern of diet represented by cell $\mathrm{E}$ could well be expected under conditions such as in parts of Africa where the staple food is a starchy root, such as cassava or plantain, with protein content of less than $2 \%$. In India, unlike Africa, with the exception of some lowincome households in Kerala, starchy roots do not form a principal part of the diet. The principal food is a cereal, e.g., rice, wheat, or jowar, which together with a small amount of pulses and vegtables goes to make up the diet for most people in the country. Irrespective of the nature of the cereal, such a diet will supply the protein needs of man provided he takes enough of it to satisfy his energy requirements. This is seen by reference to Table 4 which is reproduced from Aykroyd \& Doughty (1964) and which shows the calculated values of NDpCal $\%$ in different foods and food mixtures. These values take account of the amino acid composition of the foods and are directly comparable with the requirements shown in Table 2. It will be seen that a wheat and pulse diet has NDPCal \% of 7 , which is more than adequate to cover the needs of man at all ages, including those of pregnant and lactating women. A rice and pulse diet is also adequate, except for pregnant and lactating women. However, the table shows that a very small amount of milk added to a rice-pulse diet will produce a mixture adequate for the special needs of this group.

Thus, it follows both from the statistical analysis of surveys of food consumption, and from the nature of the foods available, that the widespread incidence of protein 
deficiency in India today is mostly the result of an inadequate quantity of food. This accords with the finding of Gopalan (1968). The critical factor, as he puts it, is the calorie intake and not protein.

How then in the light of these findings can be justified the call to increase production of protein in all forms, irrespective of whether these forms are high or low in calories. This call is based on the widespread belief that the principal deficiency in diets is likely to be protein and not calories, and that infants and children need foods which are much more concentrated in protein than those which are adequate for adults. Great emphasis was placed upon the need for protein-rich foods because the old scales of protein requirements (e.g. Indian Council of Medical Research, I958; FAO, 1957) were much higher than the revised recommendations (Indian Council of Medical Research, I968; FAO, 1965). If these new scales are accepted we must conclude that children's needs for protein can be met with a diet based on cereals and pulses, such as those normally eaten by adults, provided they take enough of it. There is therefore no particular danger of protein deficiency occurring once an infant begins to take solid food and can tolerate the bulk associated with it without impairing his digestive capacity. Protein-rich foods of high biological value, such as milk and eggs, have clearly a vital part to play in ensuring a smooth transition in the diet of recently weaned infants and also in providing the nutrition needed during states of pregnancy and lactation.

\section{REFERENCES}

Aykroyd, W. R. \& Doughty, J. (1964). F.A.O. nutr. Stud. no. I9.

Aykroyd, W. R., Gopalan, C. \& Balsubramanian, S. C. (1966). Spec. Rep. Ser. Indian Coun. med. Res. no. 42.

Calloway, D. H. \& Spector, H. (1954). Am. f. clin. Nutr. 2, 405.

FAO (1957). F.A.O. nutr. Stud. no. r6.

FAO (1965). F.A.O. Nutr. Mtg Rep. Ser. no. 37.

Gopalan, C. (1968). In Calorie Deficiencies and Protein Deficiencies. [R. A. McCance and E. M. Widdowson, editors.] London: J. \& A. Churchill.

Indian Council of Medical Research (1958). Recommended Dietary Allowances for Indians. Delhi: Indian Council of Medical Research.

Indian Council of Medical Research (1968). Recommended Dietary Allowances for Indians. Delhi: Indian Council of Medical Research.

Miller, D. S. \& Payne, P. R. (196I). F. Nutr. 74, 413.

Ramalingaswami, V., Deo, M. G. \& Sood, S. K. (196r). Publs natn. Res. Coun., Wash. no. 843, p. 365.

Srikantia, S. G. \& Gopalan, C. (1959). F. appl. Physiol. 14, 829.

Sukhatme, P. V. (196r). fl R. statist. Soc. 124, 463 .

Sukhatme, P. V. (1963). Statistica neerland. r7, no. 4 , p. 401.

Sukhatme, P. V. (1965). Feeding India's Growing Millions. Bombay: Asia Publishing House.

Sukhatme, P. V. (1966). Fl R. statist. Soc. 129, 222. 